\title{
Isolation of Phosphate Solubilizing Microorganism from Rhizospheric Medium Black Soil of Yavatmal District (MH), India
}

\author{
D.L. Wasule*, R.M. Gade, R.M. Shinde and S.P. Bobate
}

Vasantrao Naik College of Agricultural Biotechnology, Yavatmal, Maharashtra, India

*Corresponding author

\begin{abstract}
A B S T R A C T
\section{Keywords}

Soil phosphorus,

Solubilization,

Nodulation,

Organic acids, $\mathrm{pH}$,

Bacillus, Chick pea

Article Info

Accepted:

04 May 2019

Available Online:

10 June 2019

\section{Introduction}

Chick pea occupies a unique position in pulse crops but its production is very low. Chick pea (Cicer arietinum L.) is more efficient than other pulses in taking up $\mathrm{P}$ from soil, as it secrets more acid which helps in solubilizing $\mathrm{P}$. Phosphorus is one of the most essential elements for plant growth after nitrogen. Phosphorus ( $\mathrm{P})$ is a major growth-limiting nutrient, and unlike the case for nitrogen, there is no large atmospheric source that can be made biologically available (Ezawa et al., 2002). Root development, stalk and stem strength, flower and seed formation, crop maturity and production, $\mathrm{N}$-fixation in legumes, crop quality, and resistance to plant

diseases are the attributes associated with phosphorus nutrition. However, the availability of this nutrient for plants is limited by different chemical reactions especially in medium black soil of Yavatmal district. Large amount of $\mathrm{P}$ applied as fertilizer enters in to the immobile pools through precipitation reaction with highly reactive $\mathrm{Al}^{3+}$ and $\mathrm{Fe}^{3+}$ in acidic, and $\mathrm{Ca}^{2+}$ in calcareous or normal soils (Gyaneshwar et al., 2002; Hao et al., 2002). It has been reported that a great proportion of phosphorus in chemical fertilizers becomes unavailable in the soil due to the formation of strong bonds of phosphorus with calcium and magnesium in alkaline $\mathrm{pH}$ and the same bonds with iron and aluminium in acidic soil. Insoluble
\end{abstract}


phosphate compounds can be solubilized by organic acids and phosphatase enzymes produced by plants and microorganisms. The PSB dissolve the soil $\mathrm{P}$ through production of low molecular weight organic acids mainly gluconic and keto gluconic acids in addition to lowering the $\mathrm{pH}$ of rhizosphere. The $\mathrm{pH}$ of rhizosphere is lowered through biotical production of proton / bicarbonate release (anion / cation balance) and gaseous $(\mathrm{O} 2 / \mathrm{CO} 2)$ exchanges. For example, PSB have been shown to enhance the solubilization of insoluble $\mathrm{P}$ compounds through the release of organic acids and phosphatase enzymes (Sharma et al., 2005). Phosphate solubilizing bacteria are considered among the most effective plant assistants to supply phosphorus at a favourable level. Phosphate deficiency in soil can severely limit plant growth, productivity of legumes, deleterious effect on nodule formation (Alikhani et al., 2006). However, a meagre work has been reported on $\mathrm{P}$ solubilisation compared to nitrogen fixation and its effect on nodulation. Therefore the present investigation was aimed to isolate and screen potential phosphate solubilising microbes from Rhizospheric medium black soil collected from Yavatmal district of Maharashtra state.

\section{Materials and Methods}

\section{Collection of soil samples}

Soil samples around Rhizosphere of Wheat, Chickpea, Safflower, Cotton crops were collected from the fields of Yavatmal districts. The samples were then air-dried, powered and mixed well to represent a single sample. The sample was then taken for the study.

\section{Isolation of PSB}

PSB were isolated from each sample by serial dilution and spread plate method. One gram (1g) of soil sample was dispersed in $9 \mathrm{ml}$ of autoclaved distilled water and was thoroughly shaken. $1 \mathrm{ml}$ of the above solution was again transferred to $9 \mathrm{ml}$ of sterile distilled water to form $10^{-2}$ dilution. Similarly $10^{-3}, 10^{-4}, 10^{-5}$, $10^{-6}$ serials were made. $0.1 \mathrm{ml}$ of each dilution was spread on Pikovskaya's agar medium (PVK) Pikovskaya RI (1948) containing insoluble Tricalcium phosphate and incubated at $27-30^{\circ} \mathrm{C}$ for 7 days. Colonies showing halo zones were picked and purified by 5 times subculture method on Pikovskaya's (PVK) agar medium for studying colony morphology Goenadi et al., (2000).

\section{Morphological characterization}

Morphological characteristics of isolates viz. shape, size, elevation, surface form, margins and surface texture, color were observed for their characterization. Lal (2002).

\section{Phosphate solubilization index}

Bacterial isolates were selected from the colonies based on their ability to form a clear halo zone on PVK agar. The isolates were aseptically spot-inoculated onto the center of the PKV agar plate. All plates were incubated at $28^{\circ} \pm 2^{\circ} \mathrm{C}$ for 7 days. Clear halo were marked as positive for phosphate solubilization. It was measured and the phosphate SI was evaluated using the following formula (Edi-Premono et al., 1996).

Solubilizing index $=[($ colony diameter + halo zone diameter)/colony diameter]

The phosphate solubilization efficiency (SE) of the isolates was calculated using following formula (Nguyen et al., 1992).

Solublizing efficiency $(\mathrm{SE})=$ (Halo zone diameter/Colony diameter) X 100

\section{Change in $\mathrm{pH}$ of medium}

Principal mechanism in of phosphate solubilisation was lowering of $\mathrm{pH}$ of media by microbial production of organic acids and mineralization of organic $\mathrm{P}$ by acid 
phosphatase. Isolates were inoculated on Pikovskaya's broth medium with neutral $\mathrm{pH}$ and observation of change in $\mathrm{pH}$ was recorded.

\section{Morphological and Biochemical characterization}

The isolate was characterized for its morphological study and gram staining. The potential isolate was subjected to fifteen different biochemical test namely Catalase, Urease, Hydrogen sulphite, Potassium hydroxide solubility, Gelatin liquefaction, Nitrate reduction, Citrate utilization, Lysine utilization, Ornithine utilization, Phenylalanine deamination, Motility, Triple sugar iron, Adonitol, Arabinose, Sorbitol following standard procedure.

\section{Results and Discussion}

Solubilizing index/ Solubilizing efficiency

Comparative study isolate PSB -1 shows maximum Solubilizing index/ Solubilizing efficiency i.e. (2.62) /(161.90\%) followed by PSB-2, PSB-3, PSB-9, PSB-6, PSB-10, PSB11, PSB-5, PSB-7, PSB-8 and PSB-4 (Table 1) (L. Moreno-Ramírez et. al., 2015).

\section{Change in pH of medium}

Comparative study of PSB isolates shows that the isolate PSB -1 shows maximum acidic $\mathrm{pH}$ i.e. (4.40) followed by PSB-2, PSB-3, PSB-5, PSB-9, PSB-7, PSB-8, PSB-10, PSB-6, PSB11 and PSB-4 (Whitelaw 2000).

\section{Morphological and biochemical} characterization

From above eleven isolates best isolate PSB-1 was used for studied for its morphological, and biochemical characteristics. In gram staining isolate PSB-1 showed gram +ve result (Table 2 and 3 ).

Table.1 Measurement of halo zone, change in $\mathrm{pH}$, Solubilizing index and Solubilizing efficiency

\begin{tabular}{|c|c|c|c|c|c|}
\hline \multirow[t]{2}{*}{ Isolates } & \multicolumn{2}{|c|}{ Halo zone(cm) } & \multirow{2}{*}{$\begin{array}{c}\text { Change } \\
\text { in pH }\end{array}$} & \multirow{2}{*}{$\begin{array}{c}\text { Solubilizing } \\
\text { index [(colony } \\
\text { diameter+halo } \\
\text { zone diameter) } \\
\text { / colony } \\
\text { diameter] }\end{array}$} & \multirow{2}{*}{$\begin{array}{c}\begin{array}{c}\text { Solubilizing } \\
\text { efficiency }\end{array} \\
\text { (Halo zone } \\
\text { diameter/Colony } \\
\text { diameter) x } 100\end{array}$} \\
\hline & $\begin{array}{l}\text { Colony } \\
\text { diameter }\end{array}$ & $\begin{array}{c}\text { Halo } \\
\text { zone } \\
\text { diameter }\end{array}$ & & & \\
\hline PSB-1 & 2.1 & 3.4 & 4.40 & 2.62 & 161.90 \\
\hline PSB-2 & 1.7 & 2.5 & 4.64 & 2.47 & 147.05 \\
\hline PSB-3 & 1.6 & 2.1 & 4.70 & 2.31 & 131.25 \\
\hline PSB-4 & 1.7 & 1.0 & 5.39 & 1.59 & 58.52 \\
\hline PSB-5 & 1.65 & 1.2 & 4.71 & 1.73 & 72.72 \\
\hline PSB-6 & 1.68 & 1.8 & 4.90 & 2.07 & 107.14 \\
\hline PSB-7 & 1.72 & 1.2 & 4.74 & 1.70 & 69.76 \\
\hline PSB-8 & 1.75 & 1.2 & 4.76 & 1.69 & 68.57 \\
\hline PSB-9 & 1.71 & 2.0 & 4.73 & 2.17 & 116.95 \\
\hline PSB-10 & 1.69 & 1.4 & 4.79 & 1.83 & 82.84 \\
\hline PSB-11 & 1.73 & 1.3 & 4.90 & 1.75 & 75.14 \\
\hline
\end{tabular}


Table.2 Study of external morphology of PSB-1 isolate

\begin{tabular}{|c|l|c|}
\hline Sr. No. & \multicolumn{1}{|c|}{ Character } & PSB-1 \\
\hline $\mathbf{1}$ & Shape & Circular \\
\hline $\mathbf{2}$ & Size of colony & $4.0 \mathrm{~cm}$ \\
\hline $\mathbf{3}$ & Colour/pigmentation & Whitish Pink \\
\hline $\mathbf{4}$ & Elevation & Elevated \\
\hline $\mathbf{5}$ & Margin & Regular \\
\hline $\mathbf{6}$ & Motility & Motile \\
\hline $\mathbf{7}$ & Bacterium shape & Rod \\
\hline
\end{tabular}

Table.3 Biochemical characterization of PSB-1 isolate

\begin{tabular}{|c|l|c|}
\hline \multirow{2}{*}{ Sr. No. } & TEST & Phosphate Solubilizing Bacteria \\
\cline { 3 - 3 } & & + \\
\hline 1 & Catalase test & - \\
\hline 2 & Urease test & - \\
\hline 3 & Hydrogen sulphite test & + \\
\hline 4 & Potassium hydroxide solubility test & + \\
\hline 5 & Gelatin liquefaction test & + \\
\hline 6 & Nitrate reduction test & + \\
\hline 7 & Citrate utilization test & - \\
\hline 8 & Lysine utilization test & - \\
\hline 9 & Ornithine utilization test & - \\
\hline 10 & Phenylalanine deamination test & + \\
\hline 11 & Motility test & + \\
\hline 12 & Triple sugar iron test & - \\
\hline 13 & Adonitol test & + \\
\hline 14 & Arabinose test & + \\
\hline 15 & Sorbitol test & \\
\hline & &
\end{tabular}

Plate No. 1: Comparison of zone of clearance of PSB isolates

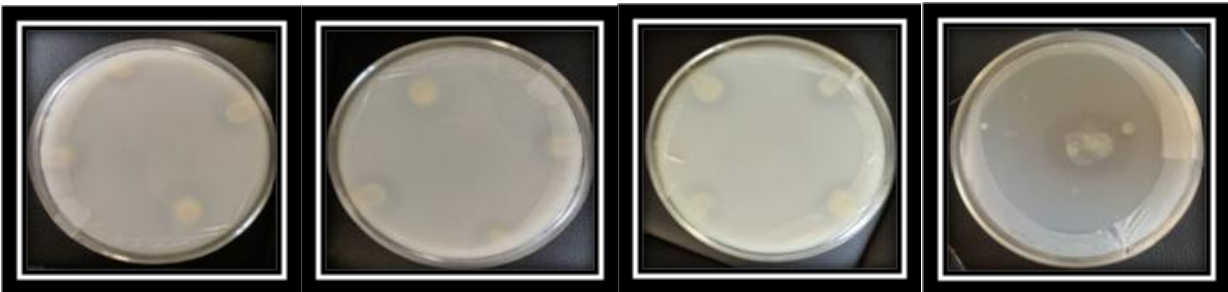

\section{Biochemical characterization}

Biochemical tests viz. Catalase test, Potassium hydroxide solubility test, Gelatin test Nitrate reduction test, Citrate utilization test, Motility test, Triple sugar ion test, Arabinose test and Sorbitol test were found to be positive, whereas Urease test, Hydrogen 
Sulphite test, Lysine utilization test, Ornithine utilization test, Phenylalanine deamination test and Adonitol test were found to be negative on the basis of biochemical reactions this isolate was identified as Bacillus $s p$.

In conclusion, phosphate solubilizing bacterial strains were isolated successfully on Pikovskaya's (PVK) agar medium. There is a close relationship between the phosphate solubilizing activity and low $\mathrm{pH}$ levels in the growth medium. This suggests that phosphate solubilization could be the results of organic acids released from bacterial metabolism, as reported in literature. As per biochemical tests the PSB-1 isolate was found to be related to Bacillus sp.

\section{Acknowledgements}

We wish to thank Dr. R. M. Gade, Associate Dean, Vasantrao Naik College of Agricultural Biotechnology, Yavatmal, Maharashtra, India for financial support, valuable encouragement and kind assistance.

\section{References}

Alikhani, H.A., Saleh, R.N. and Antoun, H., 2006. Phosphate solubilisation activity of rhizobia native to Iranian soils. Plant Soil: 287: 35-41.

Edi-Premono M, Moawad AM and Vlek PLG (1996). Effect of phosphate-solubilizing Pseudomonas putida on the growth of maize and its survival in the rhizosphere. Indones. J. Crop Sci. 11: 13-23.

Ezawa, T., S. E. Smith and F. A. Smith. 2002. P metabolism and transport in AM fungi. Plant
Soil 244:221-230.

Goenadi, D. H., Siswanto and Y. Sugiarto. 2000. Bioactivation of poorly soluble phosphate rocks with a phosphorus-solubilizing fungus. Soil Sci. Soc. Am. J. 64:927-932.

Gyaneshwar, P., G. N. Kumar, L. J. Parekh and P. S. Poole. 2002. Role of soil microorganisms in improving $\mathrm{P}$ nutrition of plants. Plant Soil 245:83-93.

Hao, X., C. M. Cho, G. J. Racz and C. Chang. 2002. Chemical retardation of phosphate diffusion in an acid soil as affected by liming. Nutr. Cycl. Agroecosys. 64:213-224.

Lal, L. 2002. In: Agrotech Pub. Academy, Udaipur, p. 224

Moreno-Ramírez L., González-Mendoza D., Cecena-Duran C. and Grimaldo-Juarez O., 2015 Molecular identification of phosphate solubilizing native bacteria isolated from the rhizosphere of Prosopis glandulosa in Mexicali valley. Genet. Mol. Res. 14 (1): 2793-2798 (2015).

Nguyen, C., Yan, W., Le Tacon, F. et al., Genetic variability of phosphate solubilizing activity by monocaryotic and dicaryotic mycelia of the ectomycorrhizal fungus Laccaria bicolor (Maire) P.D. Orton. Plant Soil (1992) 143: 193. https://doi.org/10.1007/BF00007873

Pikovskaya RI 1948 Mobilization of phosphorus in soil in connection with vital activity of some microbial species. Microbiology 17:362-370

Sharma, K. 2005.In: Manual of Microbiology. Isolation, Purification and Identification of Bacteria. Ane Books Pub. New Delhi, p. 41

Whitelaw MA (2000). Growth promotion of plants inoculated with phosphate solubilizing fungi. Edited by Donald L. Sparks. Advances in Agronomy, Academic press 69: 99-151.

\section{How to cite this article:}

Wasule, D.L., R.M. Gade, R.M. Shinde and Bobate, S.P. 2019. Isolation of Phosphate Solubilizing Microorganism from Rhizospheric Medium Black Soil of Yavatmal District (MH). Int.J.Curr.Microbiol.App.Sci. 8(06): 415-419. doi: https://doi.org/10.20546/ijcmas.2019.806.046 